\title{
The impact of loyalty programmes in a B-to-B context: Results of an experimental design
}

Received (in revised form): 3rd July, 2008

\section{Peter Daams}

has held the position of Marketing Executive, Business Services at a supplier of office products and services in the Netherlands. Currently he is an independent marketing consultant.

\section{Kees Gelderman}

is Associate Professor of Purchasing and Marketing Management at the Open University of the Netherlands. His research includes buyer-supplier relationships, business marketing and purchasing (portfolio) management. He has published in international journals including Industrial Marketing Management, the Journal of Supply Chain Management and the Journal of Purchasing and Supply Management.

\section{Jos Schijns}

is Assistant Professor in the School of Management at the Open University of the Netherlands. His research includes multichannel management, customer loyalty, customer satisfaction, customer loyalty programmes, customer publishing, relationship marketing and direct marketing. He is a member of the Professors' Academy of the Direct Marketing Educational Foundation (DMEF).

Keywords loyalty programme, behavioural loyalty, attitudinal loyalty, selection effect, customer relationship management

Abstract Studies on the effects of customer loyalty programmes have produced ambiguous and mixed results, while researchers have not widely explored the impact of loyalty programmes in a Bto-B context. This study aims to contribute to our knowledge about the impact of loyalty programmes on the loyalty of customers in business markets. While most studies are based on cross-section data, panel data and Dirichlet models, we have used a powerful, classic before-and-after experimental design in a real-life setting. The data allowed for testing hypotheses on the loyalty effect and the selection effect of a loyalty programme that was introduced by a supplier of office products. The results indicate that a customer loyalty programme, even in a B-to-B setting, has a significant and positive effect on both behavioural and attitudinal loyalty. The findings suggest that participants in the programme change their purchase behaviour and that they feel more committed since joining. In addition, a selection effect was found, indicating that loyalty programmes attract customers who were more loyal, even before joining the programme.

Journal of Tarreting, Measurement and Analysis for Marketing (2008) 16, 274-284. doi:10.1057/jt.2008.21; published online 20 October 2008

\section{INTRODUCTION}

An overwhelming number of studies have discussed and tested the concept of customer

\footnotetext{
Correspondence: Jos Schijns, School of Management, Open University of the Netherlands, P.O. Box 2960, Heerlen 6401 DL, The Netherlands. Tel: + 31455762196 ;

Fax: + 3145 5762103;

E-mail: jos.schijns@ou.nl;

Web: www.ou.nl
}

loyalty ${ }^{1-6}$ and its relationship with other variables. $^{7-13}$ In spite of the growing number of loyalty programmes, much less research has dealt with the effectiveness of such programmes. ${ }^{14,15}$ Most researchers have studied loyalty in a consumer context. Considering the nature of large B-to-B transactions and the rewards associated with maintaining loyal business customers, ${ }^{12}$ surprisingly only few studies are set in a B-to-B context. ${ }^{16}$ 
In spite of the growing number of academic studies, views differ as to the actual impact of such programmes. ${ }^{17}$ Some studies reported a positive impact on loyalty, ${ }^{18,19}$ while others did not find evidence for an impact of loyalty programmes ${ }^{20-22}$ or even reported that loyalty programmes do not help to generate referrals, but instead can foster the wrong attitude. ${ }^{23} \mathrm{~A}$ substantial body of research appears to be inconclusive as to the actual impact of loyalty programmes on customer loyalty. These mixed findings have contributed to a heated discussion on whether loyalty programmes create loyalty or whether they encourage customers to shop around and discourage loyalty. Bandyopadhyay and Martell ${ }^{2}$ point to an unclear understanding of the loyalty concept and at the inability of 'numerous' studies to produce generalisable results. A reason for the inability to produce generalisable results might be found in the application of different research designs and methods of data collection and analysis. ${ }^{17}$ Most studies are based either on surveys that only gather post-launch data or on empirical generalisations using Dirichlet models, purchase data and/or household panel data.

In an ideal research design, relevant data are collected before and after the launch of a loyalty programme in a real-life setting (as opposed to a laboratory study). Few researchers use such a powerful, classic before-and-after experimental design, however. The majority of studies evaluate the impact of loyalty programmes by using postlaunch data. In practice, pre-launch data are often unavailable and cannot be collected post hoc (Sharp and Sharp, ${ }^{20}$ p. 476). In order to assess the true impact of a loyalty programme, a before-andafter experimental design is required, collecting pre- and post-launch data from a treatment group (customers who participate in the loyalty programme) and a control group (customers who do not participate).

This study contributes to the existing literature in a number of ways. First, we assess the effects of a loyalty programme using a classic before-andafter experimental design, with pre-launch data and post-launch data gathered from participants and nonparticipants of a loyalty programme. Secondly, we study both the behavioural and the attitudinal dimensions of loyalty. Most studies are limited to the behavioural effects of a loyalty programme. Thirdly, we investigate the impact of a loyalty scheme in a B-to-B context. Most empirical research focuses on B-to-C relationships and researchers have not widely explored the impact of loyalty programmes in a B-to-B context. ${ }^{12}$ Fourthly, we take the selection effect of loyalty programmes into account. 'Most methodologies used do not account for the selection effect of loyalty programmes, leading to biased results'. ${ }^{17}$

\section{THEORETICAL BACKGROUND}

\section{Loyalty and loyalty programmes}

Many studies have defined loyalty from a behavioural perspective, ${ }^{24,25}$ while other studies suggest that attitude should be included along with behaviour to define loyalty. ${ }^{5,26}$ Oliver $^{27}$ (p. 392) defined loyalty as 'a deeply held commitment to re-buy or re-patronize a preferred product/service consistently in the future, thereby causing repetitive same-brand or same-brand-set purchasing despite situational influences and marketing efforts having the potential to cause switching behaviour'. Consistent with this definition, a two-dimensional conceptualisation of loyalty is proposed that incorporates both behavioural and attitudinal aspects. ${ }^{1,2,4-6,27-31}$ In this study, we will investigate both the behavioural and the attitudinal aspect of customer loyalty.

A loyalty programme is defined by $\mathrm{Yi}$ and Jeon ${ }^{14}$ as a marketing programme that is designed to build customer loyalty by providing incentives to profitable customers. Loyalty programmes are obviously aimed at stimulating customer loyalty. More specifically, loyalty programmes are structured marketing efforts that reward and encourage loyal behaviour. ${ }^{20}$ The most essential feature of a loyalty programme is that it rewards valued behaviour of customers.

Current research results on the effects of customer loyalty programmes seem to be ambiguous. Rosenspan, ${ }^{23}$ for example, illustrates how a loyalty programme does not always create loyalty, but instead can foster the wrong attitude. He argues that loyalty programmes do not 
necessarily foster good feelings towards the product or service, help generate referrals or even affect attitude.

Sharp and Sharp ${ }^{20}$ analysed a large (multiple participant) loyalty programme in terms of its repeat purchase loyalty effectiveness, using the Dirichlet model. This model provides the baseline against which the changes that may be brought about by a loyalty programme can be evaluated. This study was not able to show that a particular loyalty programme had brought about substantial changes in repeat purchase loyalty. The conclusion was that it is very difficult to change the fundamental repeat purchase patterns of markets. Sharp and Sharp ${ }^{20}$ (p. 485) suggest, however, that 'it is clearly possible to alter repeat purchase patterns, at least to a small degree, and loyalty programs are probably the only marketing effort which deliberately focuses on bringing about such change'.

Research by Dowling and Uncles ${ }^{21}$ and MeyerWaarden and Benavent ${ }^{32}$ suggests that most loyalty schemes do not substantially change market structures, which is in line with the conclusion of Sharp and Sharp. ${ }^{20}$ Dowling ${ }^{33}$ concludes that companies need a loyalty programme if they want to be a player in the lodging industry. O'Brien and Jones ${ }^{18}$ argue that rewards programmes do create loyalty, provided that the company understands how to share value. Similarly, Grinnell ${ }^{19}$ posits that loyalty programmes can only be successful if they are well crafted and properly executed. Using market-wide household panel data on supermarket purchases, Leenheer et al. ${ }^{34,35}$ found that loyalty programmes relate positively to share-of-wallet, although the programmes differ widely in effectiveness. Some programmes turned out to be quite ineffective.

Despite the prevalence of loyalty programmes all over the world, empirical research on the effects of loyalty programmes is still relatively scarce, ${ }^{14}$ especially in a B-to-B setting. In business marketing, it is not self-evident that a loyalty programme might be an appropriate tool for building relationships with customers. Companies need products and services to feed, support and maintain business processes, while consumers strive for satisfaction of their needs. Professional buyers are believed to behave more rationally and less emotionally than consumers, ${ }^{36}$ which might reduce the potential effectiveness of loyalty programmes in a B-to-B context. In addition, many companies have policies with regard to the receipt by employees of gifts from suppliers. The principles and standards of ethical supply management conduct, which have been developed by The Institute for Supply Management, ${ }^{37}$ recommend that supply professionals 'avoid (...) the acceptance of gifts, entertainment, favor or services from (...) suppliers that might influence, or appear to influence, supply management decisions'. Besides loyalty programmes, especially in a B-to-B context, other antecedents of business-to-business loyalty have been proposed, such as perceived risks and absence of choice. ${ }^{12}$ Relationship quality, trust, involvement, satisfaction, purchase development and switching costs are constructs that have been linked to loyalty in the B-to-B context. 7,9,10,12 Our study aims at identifying the effects on both attitudinal and behavioural loyalty after the introduction of a loyalty programme in a B-to-B context, using an experimental design with a pre- and postmeasurement. We also investigate whether the loyalty programme generates a selection effect.

\section{Behavioural loyalty}

Behavioural loyalty refers to patterns of repeat purchasing of a brand/product as a manifestation of loyalty. ${ }^{38}$ Loyalty programmes are structured marketing efforts that reward, and therefore encourage, loyal behaviour (Sharp and Sharp, ${ }^{20}$ p. 474). It is therefore felt that loyalty programmes bring about a substantial change in repeat purchase patterns.

Loyalty programme members should show changes in loyalty that are not evident among nonprogramme members. For example, Leenheer et al. ${ }^{34,35}$ state that customers identify with a company more strongly and become more (behaviourally) loyal if they are members of the loyalty programme. Therefore, the following hypothesis can be formulated:

$\mathbf{H}_{1}$ : B-to-B customers who participate in a loyalty programme show increased behavioural loyalty, whereas the behavioural loyalty of nonparticipants does not change significantly. 


\section{Attitudinal loyalty}

Besides changes in repeat buying structures, loyalty programmes are expected to foster good feelings towards the product or service and to affect attitude. Therefore, the following hypothesis can be formulated.

$\mathbf{H}_{2}$ : B-to-B customers who participate in a loyalty programme show an increased attitudinal loyalty, whereas the attitudinal loyalty of nonparticipants does not change significantly.

\section{Selection effect}

Loyalty schemes are most attractive to customers who are heavy users/buyers and are least attractive to light users/buyers. ${ }^{20}$ Therefore, a loyalty programme can attract those customers who are loyal already, since the programme is most beneficial to them. It is, however, a win-win situation, since members can identify themselves with the programme, which is most beneficial for companies with poor data about their customers. ${ }^{21}$ The loyalty programme becomes the vehicle to target loyal customers, since they choose to join the programme. In this way, the loyalty programme identifies those customers who are (behaviourally and/or attitudinally) loyal, and is self-selecting and individually correcting. ${ }^{18}$

With respect to the selection effect, the following hypothesis can be formulated:

$\mathbf{H}_{3}$ : There is a significant difference in loyalty, either behavioural or attitudinal, between participants and nonparticipants that already existed before the introduction of the programme.

\section{RESEARCH METHOD}

\section{Research design}

This study is designed to assess the impact of a loyalty programme on customer loyalty, for the customers of a single supplier of office products and services in the B-to-B market, located in the Netherlands. The loyalty programme investigated here can be described as a reward scheme offering delayed, accumulating economic benefits to customers who buy from the supplier in question. These benefits are represented in the form of points that can be exchanged for gifts, free products or aspirational rewards. In order to test our hypotheses, we have conducted an empirical study in which we match customer loyalty attitude data with purchase behaviour data.

An experimental design has been developed for comparing customer data (behavioural and attitudinal) before and after the introduction of a customer loyalty programme. By applying beforeand-after experimental designs, one can measure the direct impact of the loyalty scheme in building positive attitudes and improving/ stimulating buying behaviour. 'In an ideal world', Taylor $^{39}$ (p. 3) suggests, 'you would measure the impact of your loyalty program initiatives just like any other marketing initiative - create a comprehensive test and control experimental design in which you "control" for the significant variables and attempt to get a pure read on the incremental benefit of just the loyalty initiative. Comparing the difference in post- vs. pre-levels for the test group against those of the control group is referred to as repeated measures'. In our study, the first measurement took place three months before the launch of the loyalty programme. The second measurement took place six months after the introduction of the loyalty programme.

The data used in this study have been derived from two sources: a survey mailed to customers of the firm, and the firm's customer database. In order to collect data on customer loyalty attitude, a mail questionnaire has been developed. Figure 1 shows the type of data gathered and the instruments used for data collection.

Data from the firm's customer database were entered into the same database as the survey responses. The client code was the key that matched the survey responses with the behavioural data on each customer.

\section{Operationalising the constructs}

Attitudinal loyalty was investigated through customer commitment. Customer commitment is 
viewed as a general attitude of attachment. ${ }^{3}$ Commitment was measured using six balanced seven-point Likert-type scales anchored 'completely disagree' (1) and 'completely agree' (7). The scales were adopted and modified from Mowday et al.'s ${ }^{40,41}$ and Porter et al.'s ${ }^{42}$ organisational commitment questionnaire and used by, among others, Beatty and Kahle, ${ }^{3}$ Kelley and Davis, ${ }^{43}$ Morgan and Hunt, ${ }^{11}$ Schijns and Schröder, ${ }^{44}$ Schijns ${ }^{13}$ and Venetis. ${ }^{45}$ Items capturing the attitudinal dimension of customer loyalty (ie customer commitment) are described in Table 1.

The second data source, the firm's customer database, was used to collect data on customer purchase behaviour. Customers were tracked across several purchase episodes. That is to say, behavioural loyalty was measured using transactional data before and after the introduction of the programme. In particular, total revenues in the period between April up to and including September in the year before the

\begin{tabular}{|c|c|}
\hline Data & Instrument \\
\hline $\begin{array}{c}\text { Behavioural } \\
\text { loyalty }\end{array}$ & $\begin{array}{c}\text { Firm's customer } \\
\text { database }\end{array}$ \\
\hline Attitudinal loyalty & Mail survey \\
\hline
\end{tabular}

Figure 1: Instruments used for data collection introduction, as well as total revenues in the same period of the year the programme was introduced, were used for analyses. Since the programme does not make use of 'points barriers', the average total purchase amount is an applicable measure. Using actual behavioural data instead of 'recalled measures', the lack of reliability is minimised. Distinguishing participants and nonparticipants in the loyalty programme, the behavioural, attitudinal and selection effect of the loyalty programme will be specified and further explored.

\section{Analysing the data}

If there is a significant increase in loyalty, either behavioural or attitudinal, with respect to (potential) members (comparison 1), and no or a marginal (nonsignificant) increase in loyalty with respect to (potential) nonmembers (comparison 2 ), we suggest that the loyalty scheme has a loyalty effect (see Figure 2).

If there is a significant difference in loyalty, either behavioural or attitudinal, between participants and nonparticipants (comparison 3) that already existed before the introduction of the programme (comparison 4), we suggest that the loyalty scheme has a selection effect (see Figure 3).

An alternative way to assess the loyalty effect is by using Structural Equation Modelling. Figure 4 shows the cause-and-effect model for attitudinal loyalty.

Table 1: Items used for measuring commitment (attitudinal loyalty), correlations $(0.123=$ pre-measurement; $0.123=$ postmeasurement)

\begin{tabular}{|c|c|c|c|c|c|c|c|}
\hline Item & Description & $\mathbf{U}$ & $\mathbf{v}$ & $\mathbf{W}$ & $\mathbf{x}$ & $\mathbf{Y}$ & $\mathbf{Z}$ \\
\hline$U$ & I feel a strong sense of loyalty towards this firm & 1 & 0.515 & 0.542 & 0.473 & 0.516 & 0.534 \\
\hline V & $\begin{array}{l}\text { My positive feelings towards this supplier are a } \\
\text { major reason to remain a customer of this firm }\end{array}$ & 0.544 & 1 & 0.571 & 0.485 & 0.509 & 0.572 \\
\hline W & $\begin{array}{l}\text { I'm willing to 'go the extra mile' to continue the } \\
\text { relationship with this firm }\end{array}$ & 0.537 & 0.560 & 1 & 0.644 & 0.686 & 0.642 \\
\hline $\mathrm{X}$ & $\begin{array}{l}\text { I'm glad this firm is my supplier for office } \\
\text { products and services }\end{array}$ & 0.490 & 0.474 & 0.619 & 1 & 0.681 & 0.673 \\
\hline Y & $\begin{array}{l}\text { The relationship my company has with this } \\
\text { supplier is worth working for }\end{array}$ & 0.530 & 0.496 & 0.650 & 0.662 & 1 & 0.637 \\
\hline Z & I feel involved with my supplier & 0.535 & 0.525 & 0.592 & 0.683 & 0.633 & 1 \\
\hline
\end{tabular}


Analyses: loyalty effect

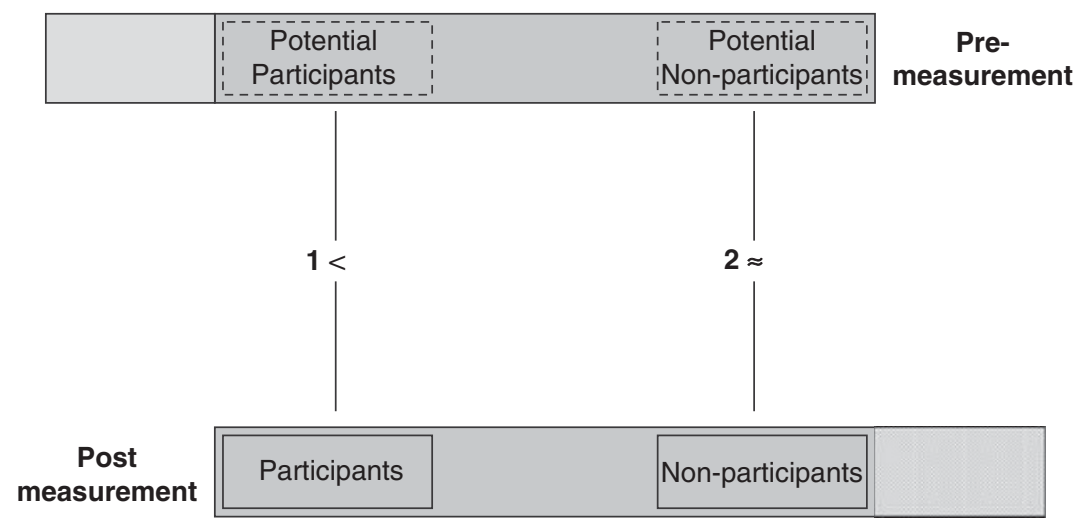

Figure 2: Analysing the loyalty effect

Analyses: selection effect

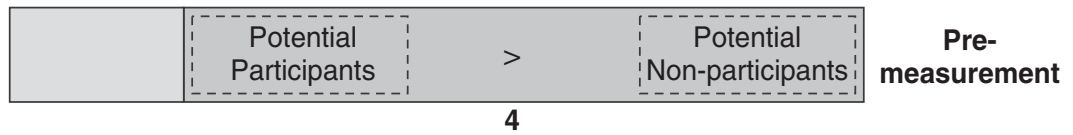

\begin{tabular}{|c|c|c|c|}
\hline $\begin{array}{c}\text { Post } \\
\text { measurement }\end{array}$ & Participants & $>$ & Non-participants \\
\hline
\end{tabular}

Figure 3: Analysing the selection effect

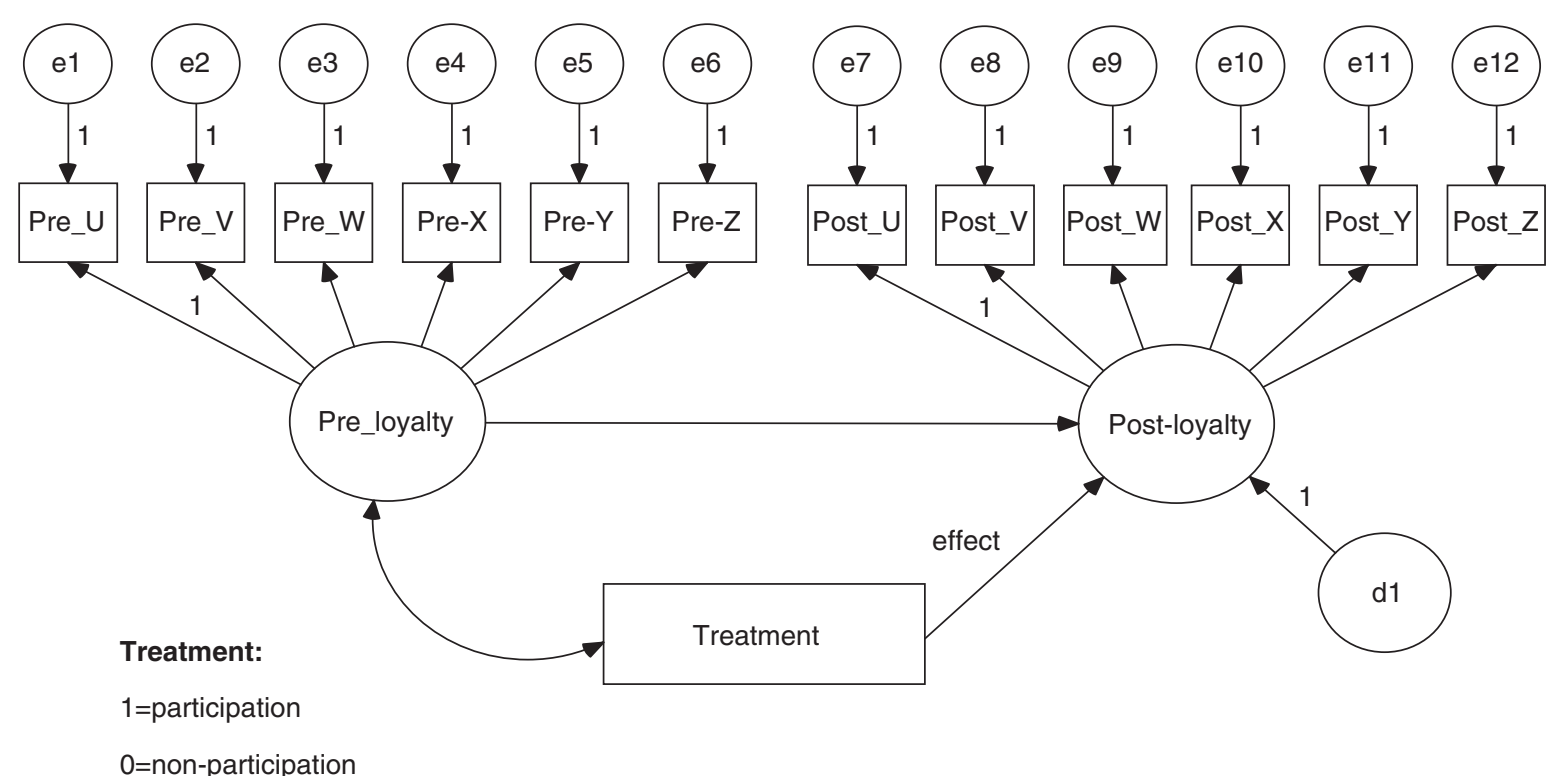

Figure 4: Measurement model for assessing the impact of a loyalty programme on attitudinal loyalty 
Conventional regression analysis is used for assessing the cause-and-effect relationship with respect to behavioural loyalty. That is, a single observed variable (total average revenues in the post-launch period) is predicted as a linear combination of two other observed variables (total average revenues in the pre-launch period and (non)participation in the programme, respectively) (Figure 5).

\section{RESEARCH RESULTS}

A total of 9953 questionnaires were mailed in order to collect pre-test data (pre-measurement). A total of 1,991 usable questionnaires were received, resulting in an effective response rate of 20 per cent. After the introduction of the loyalty scheme, these 1,991 respondents were invited to participate in the post-measurement. The response was 54 per cent, and 1,080 respondents were included in the analyses, comprising 495 nonparticipants and 585 participants.

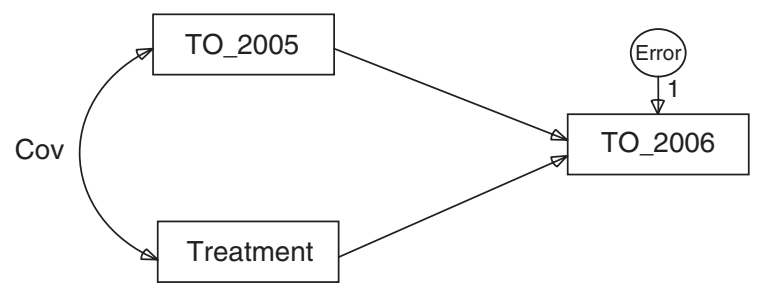

Treatment: $1=$ participation $0=$ non-participation

Figure 5: Regression analysis for assessing the impact of a loyalty programme on behavioural loyalty

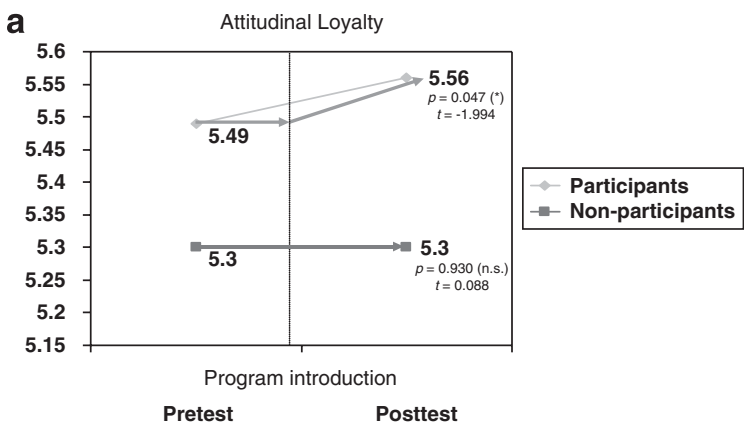

The scale used for measuring attitudinal loyalty (customer commitment) demonstrated an adequate internal consistency. The Cronbach's alpha values for the pre- and post-measurement were 0.89 , much higher than Malhotra's ${ }^{46}$ (p. 305) minimum value of 0.60 for satisfactory internal consistency reliability. Attitudinal loyalty (customer commitment) increased significantly $(p=0.047)$ from 5.49 to 5.56 for participants, and did not increase for nonparticipants (see Figure 6a and Table 2). Moreover, behavioural loyalty (average total revenues during April-September) increased significantly $(p=0.000)$ from $€ 3,027$ to $€ 3,455$ for participants, and did not change significantly for nonparticipants (see Figure $6 \mathrm{~b}$ and Table 3 ). These results suggest that the loyalty programme helps building loyalty. We can accept hypotheses $\mathrm{H}_{1}$ and $\mathrm{H}_{2}$.

The loyalty programme also has a selection effect. There is a significant difference in loyalty, both behavioural and attitudinal, between participants and nonparticipants that already existed before the introduction of the programme. This leads us to accept $\mathrm{H}_{3}$.

In fact, the differences that existed before the introduction of the programme increased due to the loyalty programme. Participants became even more loyal after the introduction of the loyalty programme. Tables 2 and 3 summarise the results for attitudinal and behavioural loyalty with respect to both the loyalty effect and the selection effect.

The cause-and-effect model shown in Figure 4 supports the results presented above. That is to say, the loyalty scheme contributes significantly to attitudinal loyalty. Since our variables are not

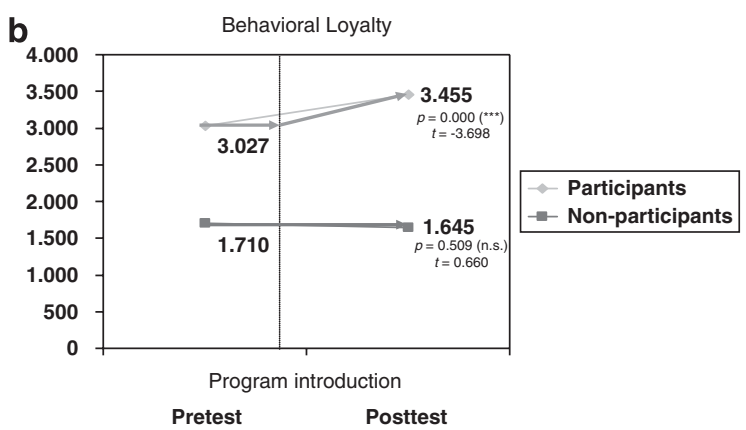

Figure 6: (a) Development attitudinal loyalty and (b) Development behavioural loyalty 
Table 2: Loyalty effect and selection effect with respect to attitudinal loyalty

\begin{tabular}{llll}
\hline Attitudinal loyalty Mean (SD) & Participants $(\boldsymbol{n}=\mathbf{5 8 5})$ & Nonparticipants $(\boldsymbol{n}=\mathbf{4 9 5 )}$ & Selection effect \\
\hline Pre-measurement & $5.49(0.88182)$ & $5.30(0.98317)$ & $p=0.001\left(^{* \star \star}\right) t=-3.357$ \\
Post-measurement & $5.56(0.87335)$ & $5.30(1.03076)$ & $p=0.000\left({ }^{\star \star \star}\right) t=-4.528$ \\
Loyalty effect & $p=0.047\left(^{*}\right) t=-1.994$ & $p=0.930$ (n.s.) $t=0.088$ & \\
\hline
\end{tabular}

NS=nonsignificant; ${ }^{*} p \leqslant 0.05 ;{ }^{* \star} p \leqslant 0.01 ;{ }^{* \star *} p \leqslant 0.001$

Table 3: Loyalty effect and selection effect with respect to behavioural loyalty

\begin{tabular}{llll}
\hline Behavioural loyalty Mean (SD) & Participants $(\boldsymbol{n = 5 8 5 )}$ & Nonparticipants $(\boldsymbol{n}=495)$ & Selection effect \\
\hline Pre-measurement & $€ 3,026.59(3,576.37)$ & $€ 1,709.89(3,245.88)$ & $p=0.000\left(^{\star \star \star}\right) t=-6.339$ \\
Post-measurement & $€ 3,455.07(4,232.29)$ & $€ 1,644.94(2,568.28)$ & $p=0.000\left(^{\star \star *}\right) t=-8.635$ \\
Loyalty effect & $p=0.000\left(^{* \star}\right) t=-3.698$ & $p=0.509($ NS) $t=0.660$ & \\
\hline
\end{tabular}

NS=nonsignificant; ${ }^{\star} p \leqslant 0.05 ;{ }^{* \star} p \leqslant 0.01 ;{ }^{* \star *} p \leqslant 0.001$

distributed joint multivariate normal, our sample size exceeds 1,000 cases and we use a relatively small model, we applied the Asymptotic Distribution Free (ADF) estimation procedure. The parameters for the model, suggesting a good fit, are as follows: chi-square/d.f. $=2.837$; $\mathrm{GFI}=0.996$; AGFI $=0.994$ and $\mathrm{RMSEA}=0.041$. Based on this model, the loyalty programme has a significant effect on post-loyalty $(t=2.783$; $p=0.005)$.

Figure 7 also shows a significant correlation between pre-loyalty and programme participation, supporting the existence of the programme's selection effect $(t=3.986 ; p=0.000)$.

Regression analysis, as illustrated in Figure 8, suggests a significant positive effect of programme membership on buying behaviour $(t=5.342$; $p=0.000)$.

With respect to behavioural loyalty, the selection effect of the loyalty programme is also supported. The significant correlation between programme participation and revenues suggests that high-spending customers are more willing to participate in the programme.

\section{DISCUSSION}

Loyalty programmes aim at building a strong emotional connection, raising customer buying behaviour and retaining profitable customers. In general, our results imply that the loyalty

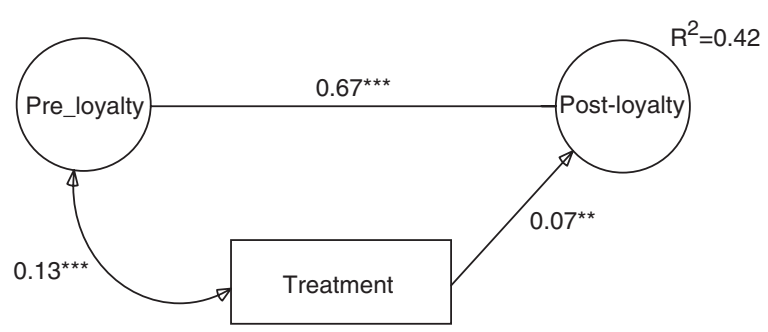

Treatment:

$1=$ participation

$0=$ non-participation

Figure 7: Structural model indicating the impact of a loyalty programme on attitudinal loyalty (standardised regression weights)

programme investigated in our study succeeded in fulfiling these aims.

Attitudinal loyalty drives behavioural loyalty. ${ }^{2,47,28}$ That is to say, buying behaviour is moderated by the individual's attitudes. 'The strength of these attitudes is the key predictor of a brand's purchase and repeat patronage' (Donio et al., ${ }^{48}$ p. 446). Therefore, in order to maximise effectiveness, the objective of loyalty programmes must be to develop high levels of attitudinal loyalty among programme participants, not just repeat buying. Higher levels of attitudinal loyalty increase customer retention by helping to insulate the programme against competitive offerings, ${ }^{28}$ creating real and perceived switching costs. 


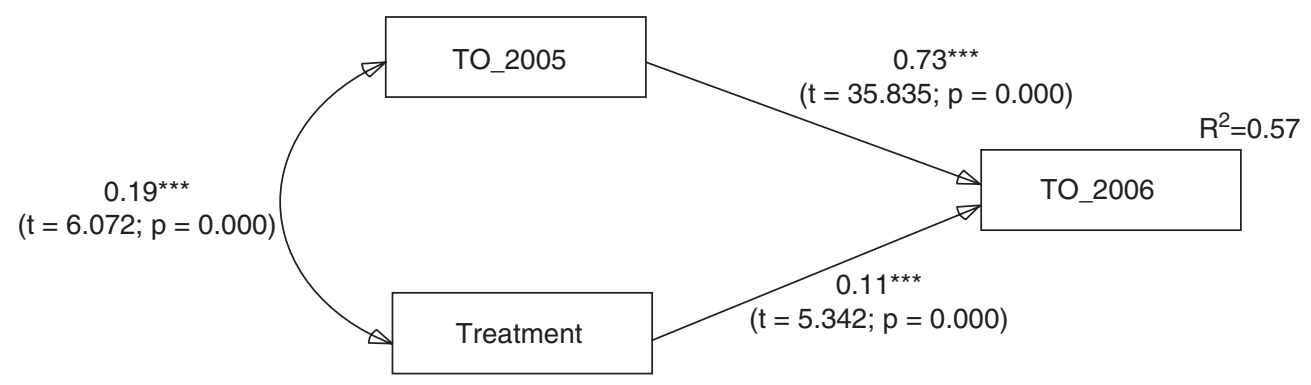

Treatment:

$1=$ participation

$0=$ non-participation

Figure 8: Regression analysis indicating the impact of a loyalty programme on behavioural loyalty (standardised regression weights)

'A programme that achieves this objective may be the most cost-effective method of helping a brand move up the hierarchy of brand leadership' (Hallberg, ${ }^{28}$ p. 240).

Loyalty programmes, particularly reward schemes, not only encourage customers to spend more but also encourage customers to become less and less sensitive to price, thus increasing profit margins. Such reward programmes provide accumulating benefits and, over time, customers are weaned away from price as the sole purchasing criterion. ${ }^{49}$

The selection effect implies that the loyalty programme helps to identify and target loyal customers, allowing the firm to become more knowledgeable about its clients ('know-how effect') and enabling the firm to approach its most loyal customers more effectively and efficiently.

This study provides a valuable insight into the impact (introduction) of a customer loyalty programme on loyalty (both behavioural and attitudinal loyalty), using an experimental research methodology as an alternative to the most frequently used cross-section research design and Dirichlet models. It is important, however, to have a reliable gauge of whether customer loyalty is positively affected by the programme relative to nonprogramme participants. By building the measure into the evaluation process, marketers can assess the long-term impact of the programme in a better way. ${ }^{28}$

\section{CONCLUSIONS}

In this paper, we analysed the loyalty effect and the selection effect of a loyalty programme using an experimental research design. With respect to the loyalty effect, it is concluded that the loyalty scheme is able to raise both attitudinal and behavioural loyalty. In addition, we found a significant difference in loyalty, both behavioural and attitudinal, between participants and nonparticipants that already existed before the introduction of the programme. This finding indicates that the programme has a selection effect too. The conclusion is that the loyalty programme makes customers more loyal, and that it attracts the most loyal customers.

With respect to the differences between participants and nonparticipants, the results obtained are consistent with results achieved by other research, ${ }^{50}$ that is, participants are more loyal than nonparticipants. In addition to the results of Dowling and Uncles, ${ }^{21}$ Gómez et al., ${ }^{50}$ and Sharp and Sharp, ${ }^{20}$ and due to our research design, we also found that it is the loyalty programme that contributes to an increase in both behavioural and attitudinal loyalty of participants. This result suggests that participants change their purchase behaviour and feel more committed after joining.

\section{DIRECTIONS FOR FUTURE RESEARCH}

We contend that there is little reason to expect that the customers of our office supply retailer 
would be different in any systematic way from the customers of other office supply retailers, and that this general framework - customers who participate in the loyalty programme become more loyal (both behavioural and attitudinal) should apply in other settings. Some directions for future research can be indicated, however. In order to support or differentiate our results, we should find answers to the following questions:

The difference in time between the introduction of the loyalty programme and the post-measurement was six months. Therefore the effects found in our study can be characterised as short-term effects. The effect of the loyalty programme is, however, interesting in the long run. Does the loyalty effect become even stronger, or will it crumble away as time goes by?

The loyalty programme in our study was described as a reward programme. Besides reward programmes, other types of loyalty programmes can be identified (eg affinity programmes, frequency programmes or customers' clubs). 'Each of these tools shows significant differences relating to its management and it is possible that this has an impact on the effect that it is able to obtain'(Gómez et al., ${ }^{50}$ p. 394). So, do other types of loyalty programmes generate similar effects, using an experimental research design?

In addition, it can be argued that the increased volume and quality of better-targeted communication, carried with the programme, creates (part of) the loyalty effect of the programme. In this study, we did not control for this potential cause of the loyalty effect. In a future research design, nonparticipants could be exposed to something similar to show the true uplift, or else some customers should be excluded from the loyalty scheme for at least a period. Another possibility would be to assess which part of the loyalty effect can be accounted for by the communication part of the loyalty programme and which part can be accounted for by the reward part of the loyalty scheme.

Finally, the effectiveness of a loyalty programme can be different depending on the type of product. ${ }^{51,52}$ Thus, there is a need to extend this study to other types of products and services than office supplies in order to find out whether our results are supported.

\section{References}

1 Baldinger, A. L. and Rubinson, J. (1996) 'Brand loyalty: The link between attitude and behaviour', Journal of Advertising Research, Vol. 36, No. 6, pp. 22-44.

2 Bandyopadhyay, S. and Martell, M. (2007) 'Does attitudinal loyalty influence behavioural loyalty? A theoretical and empirical study', Journal of Retailing and Consumer Services, Vol. 14, pp. 35-44.

3 Beatty, S. E. and Kahle, L. R. (1988) 'Alternative hierarchies of the attitude-behaviour relationship: The impact of brand commitment and habit', Journal of the Academy of Marketing Science, Vol. 16, No. 1, pp. 1-10.

4 Day, G. S. (1969) 'A two-dimensional concept of brand loyalty', Journal of Advertising Research, Vol. 9, No. 3, pp. 29-35.

5 Dick, A. S. and Basu, K. (1994) 'Customer loyalty: Towards an integrated conceptual framework', Journal of the Academy of Marketing Science, Vol. 22, No. 2, pp. 99-113.

6 Liddy, A. (2000) 'Relationship marketing, loyalty programmes and the measurement of loyalty', Journal of Targeting, Measurement and Analysis for Marketing, Vol. 8, No. 4, pp. 351-362.

7 Bennett, R., Hartel, C. E. J. and McColl-Kennedy, J. R. (2005) 'Experience as a moderator of involvement and satisfaction on brand loyalty in a business-to-business setting 02-314R', Industrial Marketing Management, Vol. 34, No. 1, pp. 97-107.

8 Donio, J., Massari, P. and Passiante, G. (2005) 'Links between satisfaction, loyalty and profitability in a company: An integrative model for the agri-food sector', An eBMS paper accepted for the 11th International Conference on Industrial Engineering and Engineering Management (IEEM), 23-25 April, Northeastern University, Shenyang, China.

9 Gounaris, S. P. (2005) 'Trust and commitment influences on customer retention: Insights from business-to-business services', Journal of Business Research, Vol. 58, No. 2, pp. 126-140.

10 Lam, S. Y., Shankar, V., Erramilli, M. K. and Murthy, B. (2004) 'Customer value, satisfaction, loyalty, and switching costs: An illustration from a business-to-business service', Journal of the Marketing Science, Vol. 32, No. 3, pp. 293-311.

11 Morgan, R. M. and Hunt, S. D. (1994) 'The commitment-trust theory of relationship marketing', Journal of Marketing, Vol. 58, No. 3, pp. 20-38.

12 Rauyruen, P. and Miller, K. E. (2007) 'relationship quality as a predictor of B-to-B customer loyalty', Journal of Business Research, Vol. 60, pp. 21-31.

13 Schijns, J. M. C. (1998) 'Measuring and managing customerorganization relationships', Thesis (Dutch text), Maastricht University, Datawyse Book productions, Maastricht.

14 Yi, Y. and Jeon, H. (2003) 'Effects of loyalty programs on value perception, program loyalty, and brand loyalty', Journal of the Academy of Marketing Science, Vol. 31, No. 3, pp. 229-240.

15 Kivetz, R. and Simonson, I. (2002) 'Earning the right to indulge: Effort as a determinant of customer preferences towards frequency program reward', Journal of Marketing Research, Vol. 39, No. 2, pp. 155-170.

16 Leenheer, J. (2004) 'The adoption and effectiveness of loyalty programs in retailing', Center Dissertation Series, Tilburg University, the Netherlands.

17 Müller, S. (2007) 'Loyalty programs and customer loyalty: A panel data analysis', Proceedings of the 36th EMAC Conference, Reykjavik, Iceland, 22-25 May. 
18 O'Brien, L. and Jones, C. (1995) 'Do rewards really create loyalty?' Harvard Business Review, Vol. 73 (May-June), pp. 75-82.

19 Grinnell, D. C. (2003) 'Loyalty programs are subject to success if they are well crafted and properly executed', Nation's Restaurant News, Vol. 37, No. 48, pp. 24, 60.

20 Sharp, B. and Sharp, A. (1997) 'Loyalty programs and their impact on repeat-purchase loyalty patterns', International Journal of Research in Marketing, Vol. 14, No. 5, pp. 473-486.

21 Dowling, G. R. and Uncles, M. (1997) 'Do customer loyalty programs really work?' Sloan Management Review, Vol. 38, No. 4, pp. 71-82.

22 Uncles, M. D., Dowling, G. R. and Hammond, K. (2003) 'Customer loyalty and customer loyalty programs', Journal of Consumer Marketing, Vol. 20, No. 4, pp. 294-314.

23 Rosenspan, A. (1998) 'Delusions of loyalty: Where loyalty programs go wrong', Direct Marketing, Vol. 60, No. 10, pp. 24-27, 61.

24 Kahn, B. E., Kalwani, M. U. and Morrison, D. G. (1986) 'Measuring variety seeking and reinforcement behaviors using panel data', Journal of Marketing Research, Vol. 23, pp. 89-100.

25 Ehrenberg, A. S. C., Goodhardt, G. J. and Barwise, P. B. (1990) 'Double jeopardy revisited', Journal of Marketing, Vol. 54, pp. 82-91.

26 Rundle-Thiele, S. R. (2005) 'Elaborating customer loyalty: Exploring loyalty to wine retailers', Journal of Retailing and Consumer Services, Vol. 12, No. 5, pp. 333-344.

27 Oliver, L. R. (1997) 'Satisfaction: A Behavioural Perspective on the Consumer', McGraw-Hill, New York.

28 Hallberg, G. (2004) 'Is your loyalty programme really building loyalty? Why increasing emotional attachment, not just repeat buying, is key to maximizing programme success', Journal of Targeting, Measurement and Analysis for Marketing, Vol. 12, No. 3, pp. 231-241.

29 Koslowsky, S. (2000) 'Attitude and behaviour: A marriage made in heaven?' Journal of Database Marketing, Vol. 7, No. 3, pp. 246-253.

30 Pritchard, M. P., Howard, D. A. and Havitz, M. E. (1992) 'Loyalty measurement: A critical examination and theoretical extension', Management Science, Vol. 38, pp. 155-164.

31 Schultz, D. E. and Bailey, S. E. (2000) 'Developing a total customer marketing programme', Journal of Targeting, Measurement and Analysis for Marketing, Vol. 8, No. 4, pp. 303-313.

32 Meyer-Waarden, L. and Benavent, C. (2006) 'The impact of loyalty programmes on repeat purchase behaviour', Journal of Marketing Management, Vol. 22, pp. 61-88.

33 Dowling, D. (1998) 'Frequent perks keep travelers loyal', American Demographics, Vol. 20, No. 9, pp. 32-36.

34 Leenheer, J., Bijmolt, T. H. A., Van Heerde, H. J. and Smidts, A. (2002) 'Do loyalty programs enhance behavioural loyalty? An empirical analysis accounting for program design and competitive effects', Discussion Paper No. 2002-65, Center, Tilburg University, the Netherlands.

35 Leenheer, J., Bijmolt, T. H. A., Van Heerde, H. J. and Smidts, A. (2007) 'Do loyalty programs really enhance behavioural loyalty? An empirical analysis accounting for self-selecting members', International Journal of Research in Marketing, Vol. 24, pp. 31-47.

36 Van Weele, A. J. (2005) 'Purchasing and Supply Chain Management - Analysis, Planning and Practice', 4th edn, Thomson Learning, Business Press, London.

37 Institute for Supply Management (2005). Principles and Standards of Ethical Supply Management Conduct, available at: http://www. ism.ws/tools/.

38 Jacoby, J. and Chestnut, R. W. (1978) 'Brand Loyalty: Measurement and Management', John Wiley and Sons, New York.

39 Taylor, K. (2005) 'Measuring the impact of loyalty initiatives', Marketing Journal, Vol. 2, No. 4, p. 3.

40 Mowday, R. T., Steers, R. M. and Porter, L. W. (1979) 'The measurement of organizational commitment', Journal of Vocational Behaviour, Vol. 14, pp. 224-247.

41 Mowday, R. T., Porter, L. W. and Steers, R. M. (1982) 'Employee-Organizational Linkages', Academic Press, New York.

42 Porter, L. W., Steers, R. M., Mowday, R. T. and Boulivan, P.V. (1974) 'Organizational commitment, job satisfaction, and turnover among psychiatric technicians', Journal of Applied Psychology, Vol. 59, No. 5, pp. 603-609.

43 Kelley, S. W. and Davis, M. A. (1994) 'Antecedents to customer expectations for service recovery', Journal of the Academy of Marketing Science, Vol. 22, No. 1, pp. 52-61.

44 Schijns, J. M. C. and Schröder, G. J. (1996) 'Segment selection by relationship strength', Journal of Direct Marketing, Vol. 10, No. 3, pp. 69-79.

45 Venetis, K. A. (1997) 'Service quality and customer loyalty in professional business services relationships: An empirical investigation into the customer-based service quality concept in the Dutch advertising industry', Thesis, Maastricht University, Maastricht.

46 Malhotra, N. K. (1996) 'Marketing Research: An Applied Orientation', 2nd edn, Prentice-Hall, New Jersey.

47 Duffy, D. L. (1997) 'The Loyalty Marketing Workbook', Cadmus Direct Marketing, Charlotte, NC.

48 Donio, J., Massari, P. and Passiante, G. (2006) 'Customer satisfaction and loyalty in a digital environment: An empirical test', Journal of Consumer Marketing, Vol. 23, No. 7, pp. 445-457.

49 Muller, E. (1998) 'Letter: “Customer loyalty programs”, Sloan Management Review, Vol. 39 (Winter), pp. 4-5.

50 Gómez, B. G., Arranz, A. G. and Cillán, J. G. (2006) 'The role of loyalty programs in behavioral and affective loyalty', Journal of Consumer Marketing, Vol. 23, No. 7, pp. 387-396.

51 Bolton, R. N., Kannan, P. K. and Bramlett, M. D. (2000) 'Implications of loyalty program membership and service experiences for customer retention and value', Journal of the Academy of Marketing Science, Vol. 28, No. 1, pp. 95-108.

52 Verhoef, P. C. (2003) 'Understanding the effect of customer relationship management efforts on customer retention and customer share development', Journal of Marketing, Vol. 67 (October), pp. 30-45. 